\title{
電析バルクナノ結晶 $\mathrm{Ni}$ 合金における 粒界安定性と機械的特性の関係
}

\author{
松 井 功* 尾 村 直 紀茨 \\ 山本剛 久** 瀧 川順 庸***
}

\section{1. は じめに}

金属材料において，強度と延性はトレードオフの関係にあ り，このトレードオフバランスの打開は普遍的な研究課題で あるとともに，様々な試みが続けられている(1)(2).このよう な中に打いて, 約 30 年間に渡ってナノ結晶メタル(3)の研究 が盛んに行われてきた。 ナノ結晶メタルは，100 $\mathrm{nm}$ 以下の 結晶粒により構成された多結晶金属材料であり，結晶粒微細 化による高強度化と粒界構造を介した変形メカニズムの発現 による高延性化が期待される材料である．1990年代は，ナ ノ結晶メタルの作製手法が開発されるとともに, 結晶粒サイ ズと硬さの関係が報告されている(4)-(7)．結晶粒が 10-20 nm まで微細化すると硬さが低下する逆ホールペッチ現象も注目 度の高いトピックとなった ${ }^{(8)}$. 2000年以降は，作製手法の 発展により, 試料における形状のバルク化・欠陥フリー化が 進み, 引張試験の実施が可能になるとともに，年を経るごと に延性が向上していった ${ }^{(9)-(12)}$. 実際に, 近年, 我々の研究 グループが作製した電析バルクナノ結晶 $\mathrm{Ni}$ 合金において は，引張強度 1.4-1.6 GPa，伸び10-15\%程度という優れた 特性が実現されている(13)-(17)。これらの高強度と高延性を 両立するための電析プロセスに打ける条件決定指針や原理 は，既に，まてりあ第55巻 $(2016)$ に新進気鋭」(18) として 報告している.

これらのマクロフィックな機械的特性評価と平行して，ナ
ノ構造解析が推し進められ, 粒界構造を介した変形メカニズ ムも明らかにされてきた。例えば，粒界からの転位放 出 ${ }^{(19)}$, 粒界すべり ${ }^{(20)}$, 結晶粒の回転 ${ }^{(21)}$, 粒界運動 ${ }^{(22) な と ゙ ~}$ である. 各メカニズムの詳細については, Ovid'ko らの解説 記事 (23)を参照されたい. すでに, 先述の逆ホールペッチ現 象が発現する結晶粒 10-20 nm を境に, 従来の変形メカニズ ムである転位運動から粒界構造を介した変形メカニズムに遷 移することが明らかにされている(24)。さらに，20 nm 以下 の微細なナノ結晶粒を有した材料における支配的な変形入力 二ズムは，その材料の粒径および変形時の温度，応力，ひず 久速度によって決定されると考えられて抢り，これらを反映 した変形メカニズムマップが提案されている(23)-(25). 今 後, これらの変形メカニズムマップを精査していくことによ りナノ結晶メタルにおける变形機構を理解・制御することが 可能になると思われていたが，ごく最近， $\mathrm{Hu}$ ら $^{(26)}$ が変形メ カニズムに影響を与える新たな因子として“粒界安定性”を 報告した.

作製ままの状態のナノ結晶メタルに抢ける粒界は，しばし ば，過剰体積などを含む非平衡な構造となってい る(27)-(29). 粒界の非平衡構造は, 比較的低温の熱処理を行 うことにより，結晶粒サイズや配向性に影響を与えることな く, 平衡状態に遷移させることができる ${ }^{(27)}$.これらの粒界 緩和は，粒界の大角化 ${ }^{(30)}$ や硬さの向上 ${ }^{(31)-(33)}$ をもたらすこ とが知られている，同時に，熱処理によって粒界拡散が起き るため, 粒界緩和とともに溶質や不純物の粒界偏析が起き

* (国研)産業技術総合研究所構造材料研究部門；1)研究員 2)グループ長 (†463-8560 名古屋市守山区下志段味穴ヶ洞2266-98)

** 名古屋大学工学研究科材料デザイン工学専攻 ; 教授

*** 大阪府立大学工学研究科物質・化学系専攻マテリアル工学分野; 教授

Connecting Grain Boundary Stability With Tensile Behavior in Electrodeposited Bulk Nanocrystalline Ni Alloys; Isao Matsui*, Naoki Omura*, Takahisa Yamamoto**, Yorinobu Takigawa***(*Structural Materials Research Institute, National Institute of Advanced Industrial Science and Technology (AIST), Nagoya. **Department of Materials Design Innovation Engine, Nagoya University, Naogya. ***Department of Materials Science, Osaka Prefecture University, Sakai)

Keywords: nanocrystalline metals, electrodeposition, Ni alloys, grain boundary stability, tensile properties 2018年 8 月 2 日受理[doi:10.2320/materia.57.479] 
る.これらの粒界緩和と粒界偏析の切り分けには, 3 次元ア トムプローブを用いた局所構造解析などが不可欠であ

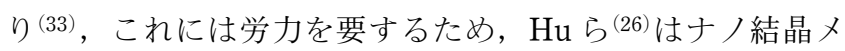
タルに打ける粒界緩和状態と偏析状態を包括的に粒界安定性 と表現し，定性的に議論を行っている。（念の為申し添える が, 一般に, 作製ままの状態が, 粒界安定性が低く, 熱処理 後の状態が, 粒界安定性が高い. ) 彼らは(26), 電析ままのナ ノ結晶 Ni-Mo 合金において, 粒界構造を介した粒界運動が 支配的な変形メカニズムであるのに対して，熱処理後におい ては粒界構造を介した変形メカニズムが抑制され部分転位に よる变形が支配的になることを報告している，このように， ナノ結晶メタルは, 同程度の粒径を有していたとしても，そ の粒界安定性によって強度や変形メカニズムが大きく異なる 可能性が示された．本稿に抢いては，この提唱されて間もな い「粒界安定性」を視点として，これまで我々が開発してき た電析バルクナノ結晶 $\mathrm{Ni}$ 合金の引張特性について議論を行 う. 加えて, 電析バルクナノ結晶合金の粒界構造制御に抢い て鍵となり得る溶質の微量添加技術について紹介する.

\section{2. 熱処理による粒界安定性の調整}

典型例として，図 $1^{(34)}$ に熱処理前後の電析 $\mathrm{Ni}-\mathrm{W}$ 合金の 透過型電子顕微鏡 $(\mathrm{TEM})$ 観察像を示す。上段が電析ままの 状態を，下段が $300^{\circ} \mathrm{C}, 24 \mathrm{~h}$ 熱処理した後の状態を示してい る. 図 1 (a) は, 電析 $\mathrm{Ni}-\mathrm{W}$ 合金が, $30 \mathrm{~nm}$ 程度の結晶粒に より構成されたナノ結晶組織を有していることを示してい る. また, 高分解能像 (図 1 (b)) は, 粒界上に析出物やアモ ルファス層が存在していないことを明らかにしている。これ は, 熱処理後も同様である (図 $1(\mathrm{~d}))$. また, 熱処理前後の 明視野像(図 1(a), 1(c))を比べると, 熱処理によって若干の
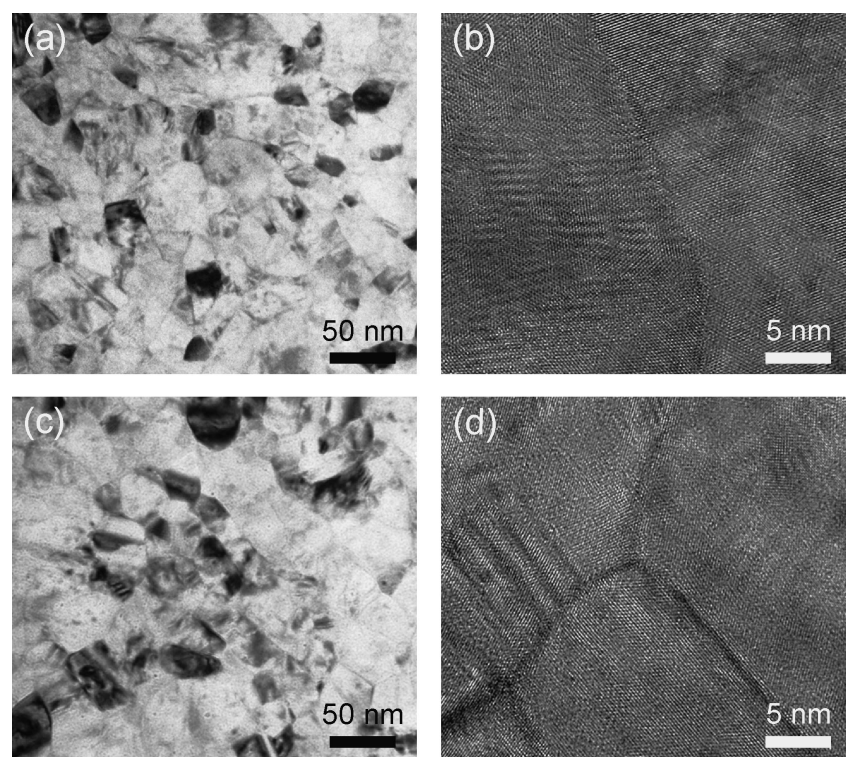

図 1 (上段)電析まま抢よび(下段)熱処理後の $\mathrm{Ni}-\mathrm{W}$ 合金の TEM 観察像 : (a) and (c) 明視野像, (b) and (d) 高分解能像 ${ }^{(34)}$.
粒成長が起きているように見える.さらに，熱処理前後の高 分解能像 (図 1(b), 1(d)) の比較においては, 電析ままの状 態においては極端に言えば粒界が波打っているのに対して, 熱処理後には粒界がより直線的になっていた．このような, 熱処理後の粒界の明瞭・直線化は, 他の文献においても報告 されている(33)(35). 前章において述べたと抢り, これらの粒 界構造の変化は, 熱処理による粒界緩和 ${ }^{(27)}$ にるものと考 えられる. 高分解能 TEM 観察により, 粒界構造変化を捉え ることは可能であるが, 観察像から対象のナノ結晶材の粒界 安定性を定量化する方法について言及された例は, 著者が知 る限り今のところない.

電析バルクナノ結晶 $\mathrm{Ni}-\mathrm{W}$ 合金に対して熱処理を施して 硬さ測定を行った．結果を図 2 (a)に示す．各熱処理温度に おける熱処理時間は $24 \mathrm{~h}$ である. $\mathrm{Ni}-\mathrm{W}$ 合金の電析ままの 硬さは $4.77 \mathrm{GPa}$ であり, 熱処理温度の上昇とともに硬さが 増加し, $300^{\circ} \mathrm{C}$ 熱処理後に最大值の $5.19 \mathrm{GPa} に$ 達した. 熱処理温度が $350^{\circ} \mathrm{C}$ にると大幅な硬さ低下が確認された. これは, 粒成長に起因するものと考えられる.これらの挙動 は，過去の Rupert ら ${ }^{(31)} \mathrm{Hu} ら^{(26)}$ の報告と一致するもの である. 本結果に示すように, ナノ結晶メタルに対して粒成 長を引き起こさないような温度域において熱処理を加えるこ とにより粒界安定性が向上し, 硬さが増加する。また，粒界 安定性は粒成長をもたらす一歩手前の温度により最大になる と考えられる(26). 我々は, 熱処理前後における硬さ測定が
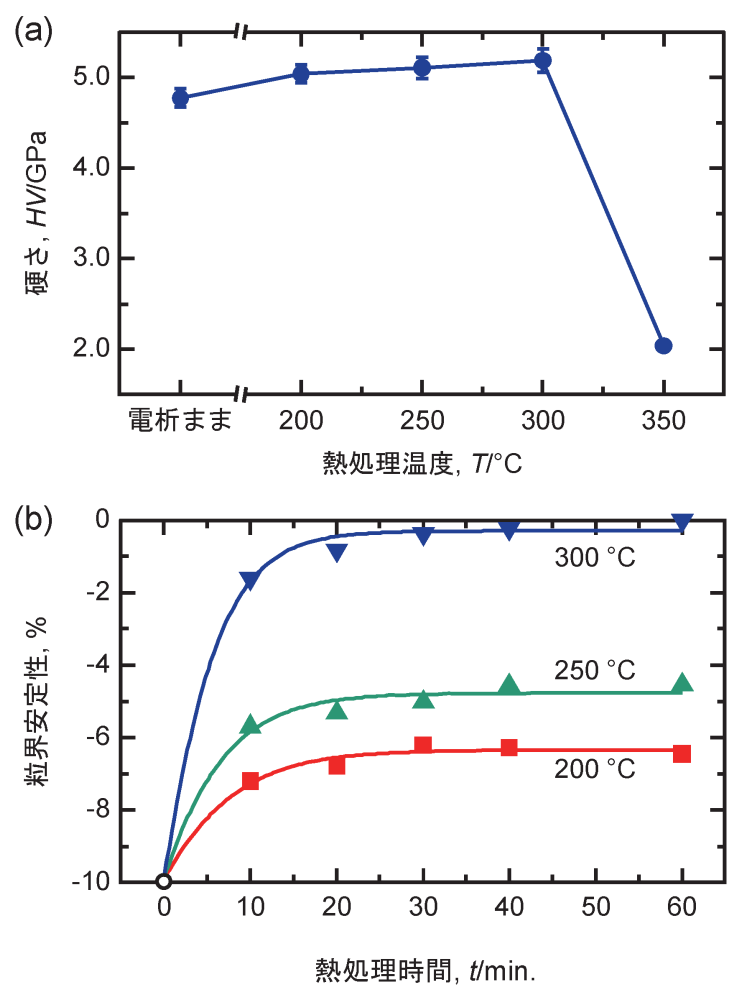

図 2 (a) 電析バルクナノ結晶 $\mathrm{Ni}-\mathrm{W}$ 合金における硬さ と熱処理温度の関係. 各温度における熱処理時 間は 24 h. (b) 電析 $\mathrm{Ni}-\mathrm{W}$ 合金における粒界安 定性と熱処理時間の関係. (オンラインカラー) 


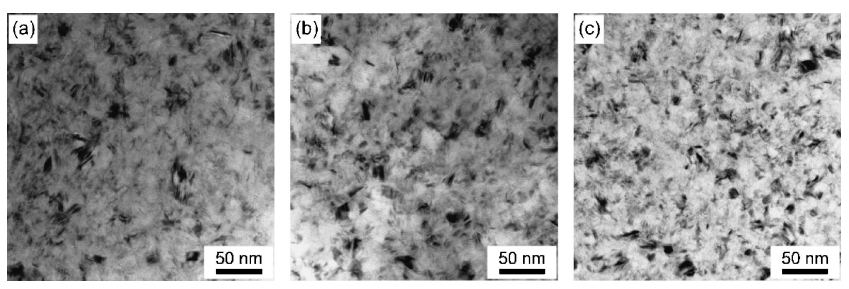

図 3 電析バルクナノ結晶 $\mathrm{Ni}-\mathrm{Fe}$ 合金の TEM 像 ${ }^{(32)}$. プロピオン酸の添加量は (a) 0, (b) 1.0 , (c) $3.0 \mathrm{~g} /$ Lである.

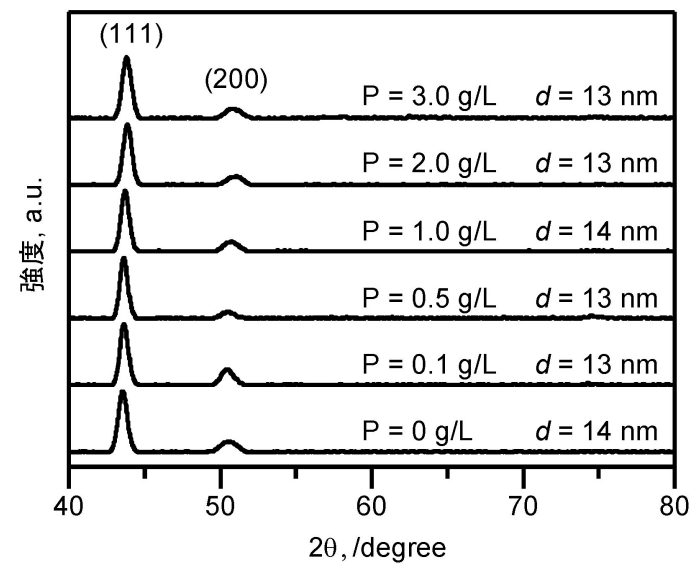

図 4 電析バルクナノ結晶 $\mathrm{Ni}-\mathrm{Fe}$ 合金の XRD パター $ン^{(32)}$. 図中の $\mathrm{P}$ はプロピオン酸添加量を, $d$ は 半值幅から算出した粒径を示す.

ナノ結晶メタルの粒界安定性を知る簡便な方法だと感じてい る. それゆえ, 便宜上ではあるが, 硬さを用いた粒界安定性, $G_{\mathrm{S}}$ の定量化を提案する.

$$
G_{\mathrm{S}}(\%)=-\left(1-H V / H V_{\max }\right) \times 100
$$

ここで, $H V$ は測定した硬さであり, $H V_{\text {max }}$ は熱処理後の最 大の硬さである。式 (1)を用いて算出した粒界安定性と熱 処理時間の関係を図 $2(\mathrm{~b})$ に示す。電析ままの状態に打い て, 粒界安定性は約 $-10 \%$ であり, 熱処理温度・時間が増 加するとともにその值はゼロに近づいていった．各温度にお いて，10分の熱処理により粒界安定性は大きく変化してお り, 粒界安定性の精密な制御には低温かつ短時間の熱処理が 必要だ分かる。 また， $\mathrm{Hu}$ ら $^{(26)}$ の報告に抢いては，粒界安 定性は結晶粒の微細化とともに低下する傾向が報告されてい る.

加えて, 電析条件が粒界安定性に影響を与える例(32)を示 す. 図 3 と図 4 は, 0-3.0 g/Lの範囲においてプロピオン酸 を添加しながら作製した電析 $\mathrm{Ni}-\mathrm{Fe}$ 合金の微細組織と X 線 回折 (XRD) パターンである. TEM 像(図 $3^{(32)}$ ) $\mathrm{XRD}$ パタ ーンから概算された粒径 (図 $4^{(32)}$ ) からは, 一見, プロピオ ン酸の影響は確認されない。一方で，図 $5^{(32)}$ に示すとおり $\mathrm{Ni}-\mathrm{Fe}$ 合金の硬さは，プロピオン酸の添加量が増加するとと もに，4.2から $5.0 \mathrm{GPa}$ に大幅に増加している. さらに，こ れらの試料に対して $200^{\circ} \mathrm{C}$ 熱処理を施すと, プロピオン酸

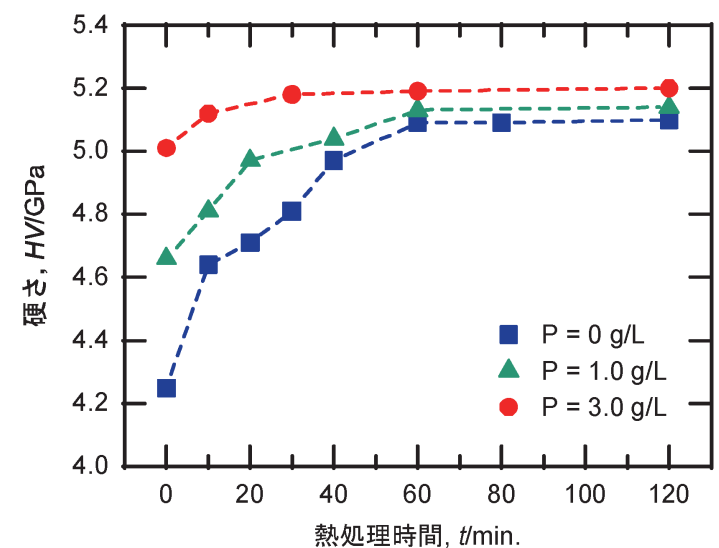

図 5 電析バルクナノ結晶 $\mathrm{Ni}-\mathrm{Fe}$ 合金における硬さと 熱処理時間の関係 ${ }^{(32)}$ 。熱処理温度は， $200^{\circ} \mathrm{C}$ であ る。また，図中の P は，プロピオン酸の添加量 を示している.（オンラインカラー）

無添加材は, 大きく硬さが上昇する. 一方で, $3.0 \mathrm{~g} / \mathrm{L}$ のプ ロピオン酸を添加して作製した $\mathrm{Ni}-\mathrm{Fe}$ 合金の硬さは，熱処 理によってほとんど上昇しない. $2 \mathrm{~h}$ の熱処理によって各試 料の硬さは 5.1-5.2 GPa とほぼ同程度の值に達している.こ れらの実験結果は，プロピオン酸が電析 $\mathrm{Ni}-\mathrm{Fe}$ 合金の粒界 安定性を増加していると考えると納得がいく. プロピオン酸 無添加材は, 電析ままの状態においては, 粒界安定性が低い ため硬さも低い值となる，一方で，プロピオン酸添加材は, 電析ままの状態においても粒界安定性が高いため, 無添加材 の熱処理後と同等の硬さを発現可能としている. 改めて, 図 3 の明視野像を比較するとプロピオン酸を $3.0 \mathrm{~g} / \mathrm{L}$ 添加して いる図 $3(\mathrm{c})$ が最も粒界が明瞭となっているようにも見え る. 残念ながら, プロピオン酸が粒界安定性を増加させる機 構については明らかにできていない. 粒界安定性に対する添 加剤の影響解明については, 今後の課題である.

\section{3. 引張特性と粒界安定性の関係}

電析バルクナノ結晶 $\mathrm{Ni}-\mathrm{W}$ 合金の熱処理前後における代 表的な応力ーひずみ曲線を図 $6^{(34)}$ に示す。引張試験片のサイ ズは主に, 平行部 $12 \mathrm{~mm}$, 幅 $3 \mathrm{~mm}$, 厚さ $1 \mathrm{~mm}$ である. ここで，各試料に対する熱処理時間は $24 \mathrm{~h}$ である。また， 得られた引張強度および $0.2 \%$ 耐力, 全伸びと熱処理温度の 関係を図 7 に示している。 $0.2 \%$ 耐力は，熱処理によって 1.03 から $1.28-1.37 \mathrm{GPa}$ に増加し, 引張強度も 1.44 から 1.57-1.62 GPa に増加した。電析 $\mathrm{Ni}-\mathrm{W}$ 合金は，電析ままの 状態においては，12.3\%という優れた伸びを示した．また， 200 と $250^{\circ} \mathrm{C}$ 熱処理後に打いては, それぞれの伸びは, 10.8\%と9.4\%であり良い伸びを維持した. 一方で, $300^{\circ} \mathrm{C} の$ 熱処理により伸びは $5.1 \%$ まで大きく減少した. 電析まま材 と $300^{\circ} \mathrm{C}$ 熱処理材の破断面を走査型電子顕微鏡 $(\mathrm{SEM})$ により 観察したが, 図 8 に示すと抢り両試験片に抢いて延性破壊時 に見られるディンプルパターンを形成していた。このことか 


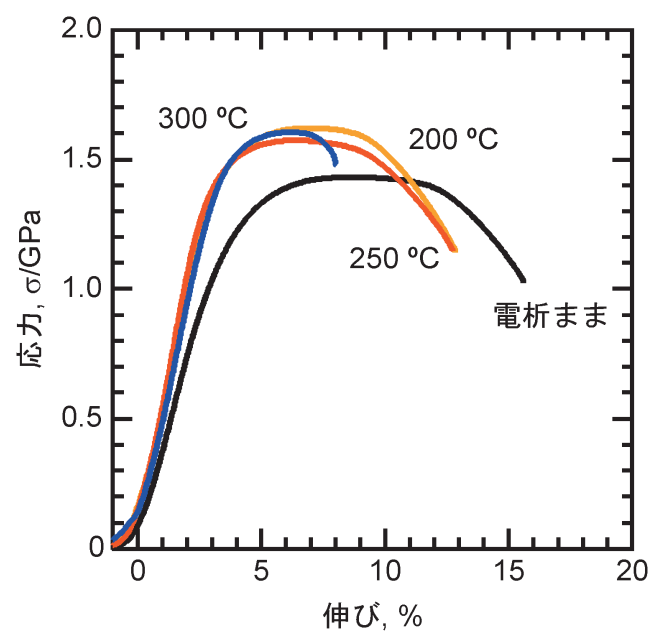

図 6 代表的な電析バルクナノ結晶 $\mathrm{Ni}-\mathrm{W}$ 合金におけ る熱処理前後の S-S カーブ(34). 各温度における 熱処理時間は， $24 \mathrm{~h}$. (オンラインカラー)
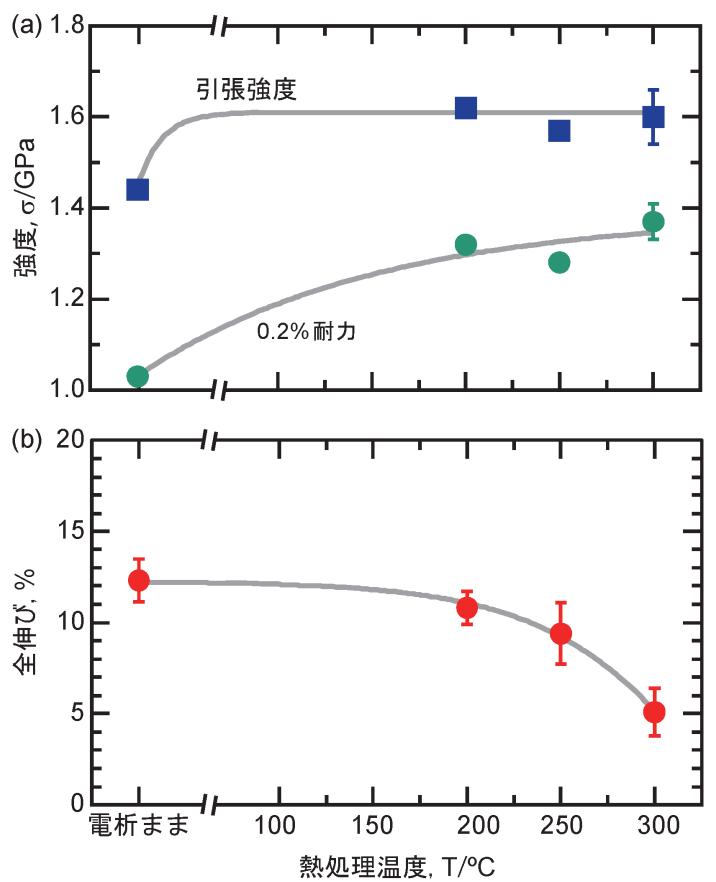

図 7 電析バルクナノ結晶 $\mathrm{Ni}-\mathrm{W}$ 合金における(a) 引張 強度， $0.2 \%$ 耐力および (b) 全伸びに対する熱処 理温度の影響(34)。(オンラインカラー)

ら, 本熱処理による伸び低下は, 粒界破壊などの脆性的な破 壊への遷移によるものでは無いと考えられた.

各特性值の変化の要因については過去に報告(34)してお り,こちらを参照されたい。ここでは, 特に, 粒界安定性と の関係について議論を行う. 図 9 に電析バルクナノ結晶(a) (b) Ni-W 合金と (c) (d) Ni-Fe 合金の引張特性を粒界安定性 に対してプロットした。 $\mathrm{Ni}-\mathrm{Fe}$ 合金は，過去に報告した $\mathrm{Ni}-$

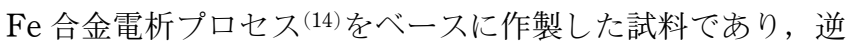
ホールペッチ領域に位置する材料である。 それゆえ, $\mathrm{Ni}-\mathrm{W}$ 合金に比べて, 電析ままの状態に扔いては, 上り低い粒界安
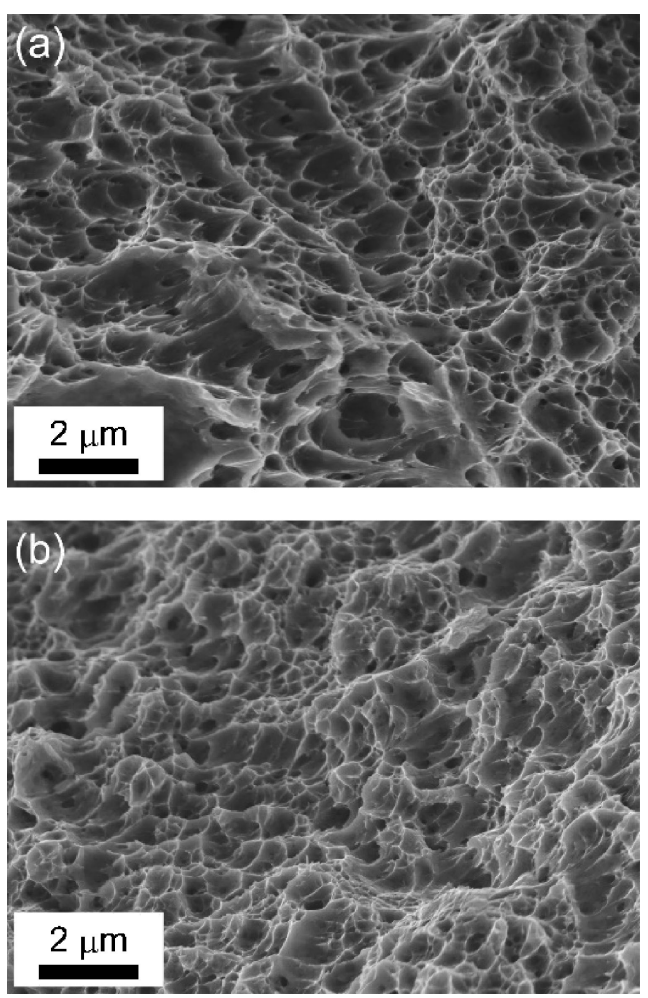

図 8 SEM により観察した引張試験後の破断面 ${ }^{(34)}$. (a) 電析ままでの $\mathrm{Ni}-\mathrm{W}$ 合金, (b) $300^{\circ} \mathrm{C}, 24 \mathrm{~h}$ の 熱処理を施した $\mathrm{Ni}-\mathrm{W}$ 合金.

定性(約-23\%) を有している。両合金に扔いて, 粒界安定 性の増加とともに $0.2 \%$ 耐力が増加し, 伸びが減少する傾向 が示された。一見, 引張特性と粒界安定性には関連があるよ うに思われるが，一方で， Ni-W 合金と $\mathrm{Ni}-\mathrm{Fe}$ 合金の粒界 安定性は大きく異なっている。 さらに，その変化量は，それ ぞれ約 $8 \%$ と約 $3 \%$ と違いが見られた。

先述のと抢り, 電析ナノ結晶 $\mathrm{Ni}-\mathrm{Fe}$ 合金に扔いては, 添 加剤を用いることにより電析ままの状態においてより高い粒 界安定性を有した試料の作製が可能となっている(図 5)。そ こで, 粒界安定性向上の手法である熱处理とプロピオン酸添 加の引張特性に対する影響について調査を行った結果を図 $10^{(32)}$ に示す, 通常の $\mathrm{Ni}-\mathrm{Fe}$ 合金に比べて, 電析浴にプロピ オン酸を添加して作製した $\mathrm{Ni}-\mathrm{Fe}$ 合金は，引張強度が約 0.1 $\mathrm{GPa}$ 向上し, 引張伸びも $10 \%$ 程度と同程度の值を示してい る. 一方で, 熱処理材 $\left(200^{\circ} \mathrm{C}, 2 \mathrm{~h}\right)$ も引張強度は約 $0.1 \mathrm{GPa}$ 増加したが, 引張伸びが $5 \%$ 程度と明確な低下が確認された。

ここまで, 粒界安定性の観点から, 電析バルクナノ結晶 $\mathrm{Ni}$ 合金の引張特性について紹介を行ってきた。各合金にお いて共通しているのは, 高い粒界安定性が $0.2 \%$ 耐力の増加 をもたらす点である. 高強度化に扔いては, 粒界安定性の増 加は有効な手段であると考えられる。一方で，伸びに対して は, 粒界安定性の大小に依らず, 熱処理の有無が大きく影響 を与えている結果となっている. 繰り返しになるが, 先行研 究 ${ }^{(26)}$ に打いては, 粒界安定性によってナノ結晶メタルの変 形メカニズムが変化することが示されている.しかしなが 

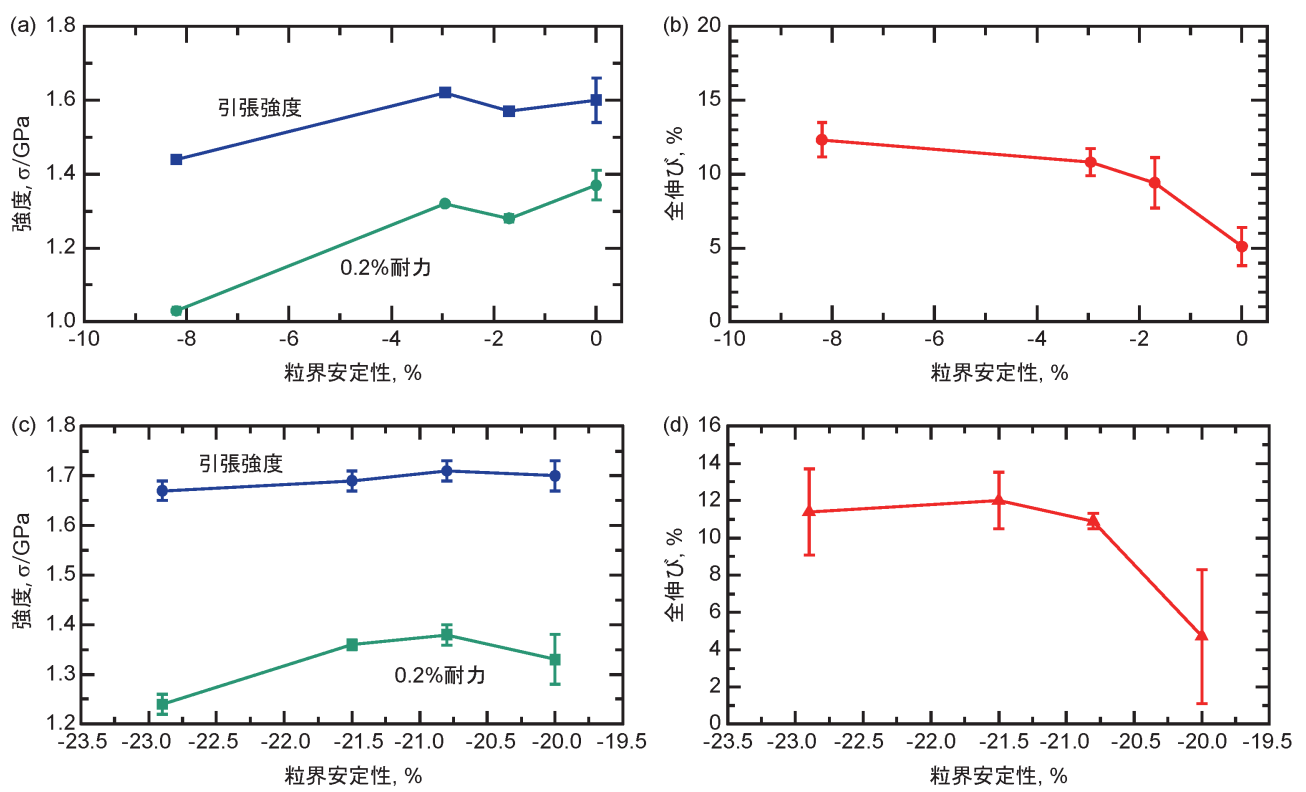

図 9 電析バルクナノ結晶 (a) (b) $\mathrm{Ni}-\mathrm{W}$ 合金と (c) (d) $\mathrm{Ni}-\mathrm{Fe}$ 合金に抢ける引張特性と粒界安定性の関係.（オンライン カラー)

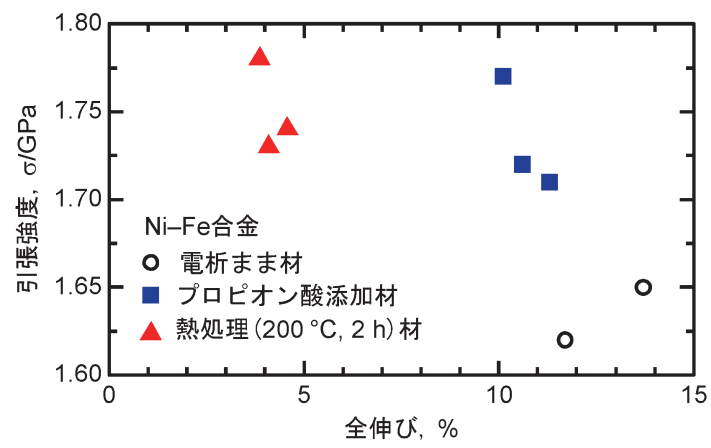

図10＼cjkstart電析バルクナノ結晶 $\mathrm{Ni}-\mathrm{Fe}$ 合金における熱処理 とプロピオン酸添加による粒界安定性向上の引 張特性に対する影響(32). (オンラインカラー)

ら, 本研究の結果からは, 粒界安定性の大小によって引張伸 びが決定されるわけではないことが示唆されている，高分解 能 TEM などにより観察される組織変化から提案された既存 の変形メカニズムが，実際の引張伸びを決定するものなの か，今後，さらに検討を進めていく必要があるように感じ る。また，これらの件に関連して, Brookら (36)が興味深い 報告を行っている. 彼らは, 粒径 10-80 nm の種々の電析バ ルクナノ結晶 $\mathrm{Ni}$ と $\mathrm{Ni}-\mathrm{Fe}$ 合金を用いて引張試験を行ってお り，その中に抢いて，粒径や $\mathrm{Fe}$ 含有量に関わらず，均一伸 びが約 $4.3 \%$ になることを示している，我々が過去に報告し た ${ }^{(34)(37)}$ 電析バルクナノ結晶 $\mathrm{Ni}-\mathrm{W}$ 合金も同様の水準を示し ている.

\section{4. 電析における溶質の微量添加技術 : 断続添加法 ${ }^{(13)}$}

粒界安定性をキーワードに電析バルクナノ結晶 $\mathrm{Ni}$ 合金の 機械的特性を評価した結果, 改めて, 粒界の状態が, ナノ結
晶メタルの特性を決定する重要な因子であることが示され た。もち万ん，粒界安定性という指標が提案される以前よ り, 粒界偏析 ${ }^{(38)}$ や粒界緩和 ${ }^{(30)}$ など粒界の状態について多く の研究がなされている，ただその一方で，依然としてナノ結 晶メタルに打いて高強度化・高延性化を実現していくうえで 明膫な材料設計指針が示されていないように感じる. 2016 年に発行された Pineau ら ${ }^{(39)}$ の解説記事においても言及され ているが，この主な要因は，プロセス由来の欠陥がアキレス 腱のごとく存在していることにある. 本稿において対象とし ている電析バルクナノ結晶 $\mathrm{Ni}$ 合金では，10\%前後の優れた 引張伸びの発現を可能にしているのは, $\mathrm{Ni}-\mathrm{Fe}$ 合 金(14)(36)(40)ならびに $\mathrm{Ni}-\mathrm{W}$ 合金(17)(34)(37), Ni-Co 合金(41)の 3 種類程度である.他の合金系は依然としてプロセス上の課 題を抱えて抢り (42)(43)，バルクナノ結晶合金の作製手法とし ては依然として改善が必要とされている。同時に，一般的な 電析プロセスは水溶液を用いるため, アルミニウムのように 水素に比して非常に碑な元素はその析出を得ること自体が困 難である。このイオン化傾向に関連した制限の打開には，非 水溶液溶媒の発展が必要である(44)-(46). 電析バルクナノ結 晶 Ni に抢ける粒界偏析の影響実証においては, さらなる電 析プロセスの発展が不可欠である. 本章においては, 特に, 水溶液プロセスに打ける合金元素種が限定される原因の一つ である溶質供給源となる試薬の不安定性に着目していきたい。

一般に， Ni， Ni 合金電析に扔いて，ホウ素による合金化を 行うために，ホウ素供給源としてジメチルアミンーボランや トリメチルアミンーボラン (TMAB)が用いられる. 残念なが ら, これらのホウ素化合物は, 酸性浴において加水分解し, 水素ガスの発生をもたらすことが知られている( ${ }^{(47)}$. 実際 に, 我々が過去に試みた $\mathrm{Ni}-\mathrm{W}-\mathrm{B}$ 合金電析に打いては, TMAB が浴中に打いて早期に加水分解するため, 試料の成 
長方向に対してホウ素が不均一に存在する結果となっ た(48). 加えて, 加水分解時に水素ガスが発生するため, こ れに起因した欠陥が電析皮膜中に導入され，特性の低下が起 きた。このような分解性の高い試薬を溶質供給源として用い るための電析技術として，我々は，新たに“断続添加法”を 開発した. 図11に一般的な電析プロセスと断続添加法の比較 を示す．従来法では，ホウ素供給源である TMABを電析溶 液に建浴時に添加している。対して, 断続添加法では, TMAB は建浴時には添加せず，電析中に断続的に添加する 手法である.この断続添加は, 装置による自動添加を容易に するため, TMAB を水に溶かしこみ, チュービングポンプ にて浴槽への滴下を行っている. また, チュービングポンプ をデジタルタイマにより制御することで，その滴下間隔・量 を調整した，以降に打いては，従来法と断続添加法で作製し た電析 $\mathrm{Ni}-\mathrm{B}$ 合金を比較する.

従来法と断続添加法によって電析 $\mathrm{Ni}-\mathrm{B}$ 合金の厚さ 1.4 $\mathrm{mm}$ 程度のバルク材を作製した. 図12は, グロー放電発光分 析 (GD-OES)によって得られたホウ素の深さ方向プロファ イルである. 従来法では, 試料の厚さが増すにつれ, ホウ素 量が減少している(図12(a))。さらに, 表面側からの測定に
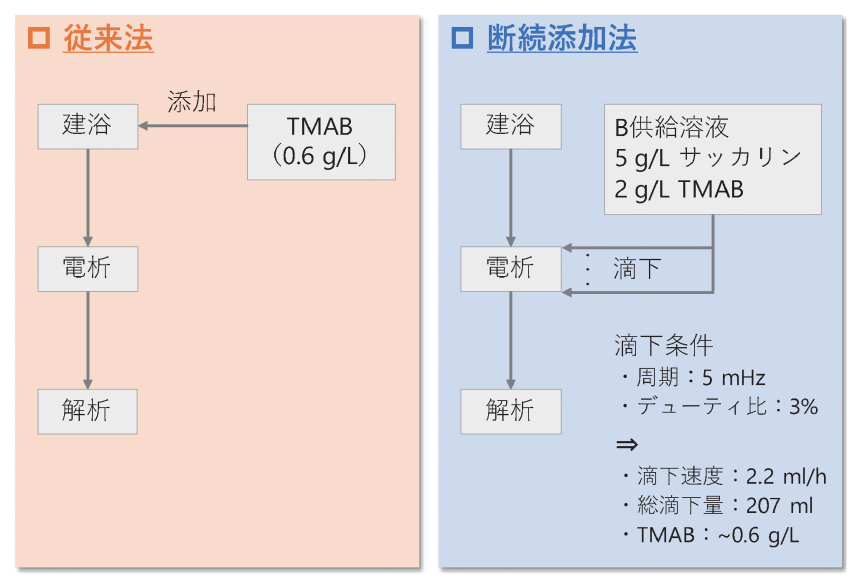

図11 従来法と断続添加法の比較. 従来法では溶質供 給源を電析前にすべて添加. 断続添加法では, 溶質供給源を電析中に断続的に添加.（オンライ ンカラー)
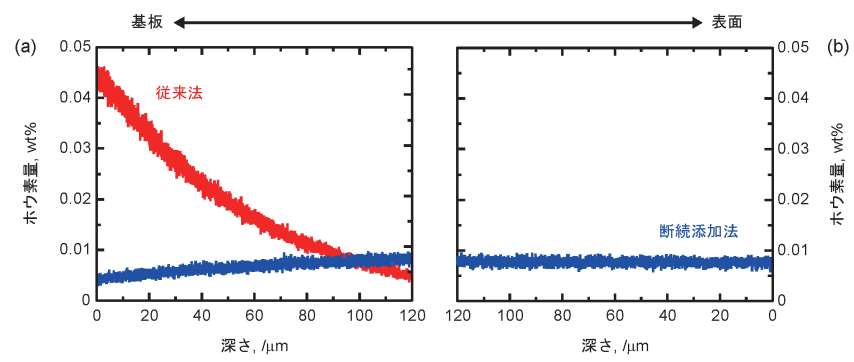

図12 GD-OES から得られたホウ素の深さプロファイ ル (13). GD-OES は, 試料の (a) 基板側からと (b) 表面側から実施. 従来法で作製した試料で は, 表面側からの分析に打いてホウ素が検出さ れていない.（オンラインカラー）
おいては, ホウ素が検出されてなかった(図12(b)). 対し て, 断続添加法では, 0.007 mass\% (0.04 at\%)のホウ素が試 料の基板側および表面側からの分析において均一に検出され た.この結果は, 断続添加法により分解性の高い試薬を溶質 供給源として適用した場合においても, 均一なバルク材の作 製が可能であることを示すものである.

図13に，各電析バルク $\mathrm{Ni}-\mathrm{B}$ 合金の XRD パターンを示し ている. 膜厚方向の均一性を評価するために, XRD 測定と 機械研磨を繰り返し実施した。図中の L は，XRD 測定を行 った箇所の基板からの距離を示している(図13(c)). 従来法 では，基板近傍では，(111)面に配向しており，また，ピー クもブロードしていた．表面側に近づくにつれ，(111)面か ら(200)面に配向が移り変わっていき, ピークもシャープに なっていた，これに対して，断続添加法では，膜厚方向によ る変化はなく, 試料全体に抢いて, (200)面に配向し, ピー クもブロードしていた. ピークのブロード変化については, 図13(d)を確認して頂きたい. 半值幅から算出した粒径と基 板からの距離の関係を示している．この図からも従来法で は, 試料が成長方向に対して不均一なのに対して, 断続添加 法では, 均一であることがよく分かる. また, 断続添加法に より作製した Ni-B 合金の粒径は約 $28 \mathrm{~nm}$ であった．電析 $\mathrm{Ni}$ 合金の粒径は, 電析条件などの影響もあるが, 主に溶質 や不純物濃度によって決定される(49)(50). 本 Ni-B 合金の木 ウ素量は， 0.04 at\% とわずかであるが，粒径を $28 \mathrm{~nm}$ まで 微細化しており, ホウ素の高い微細化能が示されている. 過 去の報告(51)に拈いても同程度の值が報告されている．

図14(13) は，各電析 $\mathrm{Ni}-\mathrm{B}$ 合金の応力ーひずみ曲線を示す。
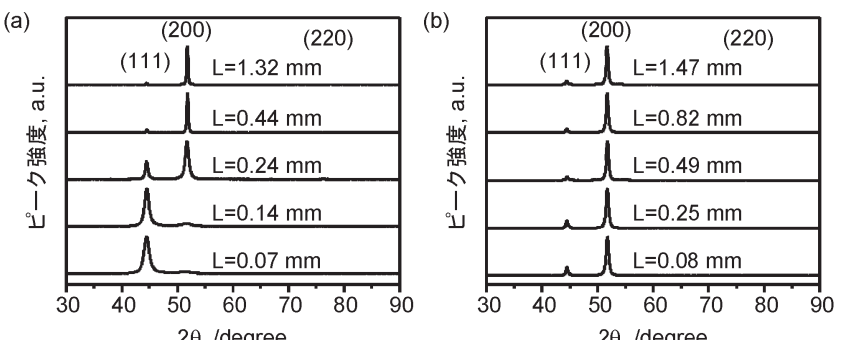

(c)
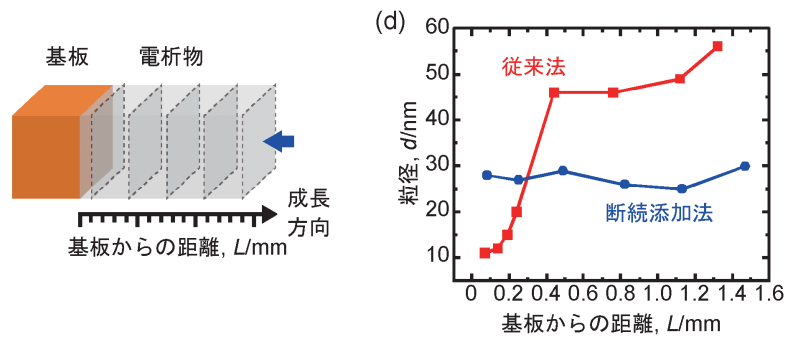

図13（a）従来法および (b) 断続添加法により得られた 電析 $\mathrm{Ni}-\mathrm{B}$ 合金の XRD パターン. (c) XRD 解析 実施方法のイメージ図. 矢印は，測定方向を示 している.（a），(b)に示すデータはXRD 測定と 機械研磨を繰り返すことで得た。図中の L は基 板からの距離を示している. (d) 得られた XRD パターンより算出した粒径と基板からの距離と の関係 ${ }^{(13)}$. (オンラインカラー) 


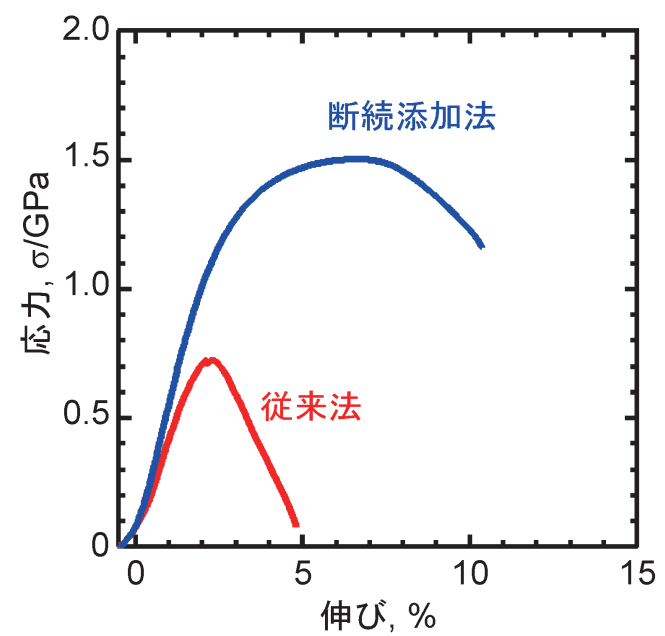

図14 従来法および断続添加法で作製した電析 Ni-B 合 金の応力ーひずみ曲線 ${ }^{(13)}$. (オンラインカラー)

従来法から得られた $\mathrm{Ni}-\mathrm{B}$ 合金は, 引張強度 $0.75 \mathrm{GPa}$, 伸 び4.5\%程度であった. 図14からも分かるとおり, 従来法に より作製した試料は，加工硬化せずに破断した。これに対し て, 断続添加法により得られたバルクナノ結晶 $\mathrm{Ni}-\mathrm{B}$ 合金 は, 引張強度 $1.45 \mathrm{GPa}$, 引張伸び $7.6 \%$ 程度と優れた特性を 示した。過去に報告された $\mathrm{Ni}-\mathrm{B}$ 合金 ${ }^{(52)}$ に比べて，引張伸 びに抢いて十分な改善が得られた。

これら引張試験片の破断後の平行部ならびに破断面の SEM 像を図15 ${ }^{(13)}$ に示す. 左側が従来法, 右側が断続添加法 である，右側の図から，断続添加法から得られた合金は，明 確にネッキングして扔り, 破断面に延性破壊時に見られるデ ィンプルパターンが形成していることがよく分かる. 対し て, 左側の図からは, 従来法から得られた合金は, 十分なネ ッキングが起きて抢らず，また，(c) と（e)の図中に赤い破線 で示す通り, 脆性的な破面と延性的な破面の二相になってい る.これは, 図12に示したと打り, 従来法に扔いては, ホ ウ素が試料全体で均一でなく $\mathrm{Ni}-\mathrm{B}$ 合金と純 $\mathrm{Ni}$ の二相から 成っており, 特に, $\mathrm{Ni}-\mathrm{B}$ 合金層において脆性的な挙動を示 したものと思われる。この主な要因は, 先述の通り, TMAB の加水分解時に水素ガスが発生することにある. 水 素ガスは, 電析皮膜への侵入と脱離を繰り返すことで, 皮膜 中に欠陥を形成もしくは大きな内部応力を発生させる．この ようなプロセスに起因した欠陥を含んだ $\mathrm{Ni}-\mathrm{B}$ 合金層におい て, 引張試験の早期にクラックが形成し, 応力集中が起きる ことで加工硬化を生じることなく破断したものと考えられ る. 一方で, 断続添加法においては, TMAB の添加量は, 従来法とトータルでは同じであるが，断続的に添加すること で分解時の水素ガスなどが非常に微量に抑えられており, こ れにより試料欠陥が形成しなかったものと考えられる.

\section{5. ま と め}

粒界の緩和状態と偏析状態を包括的に表現した粒界安定性
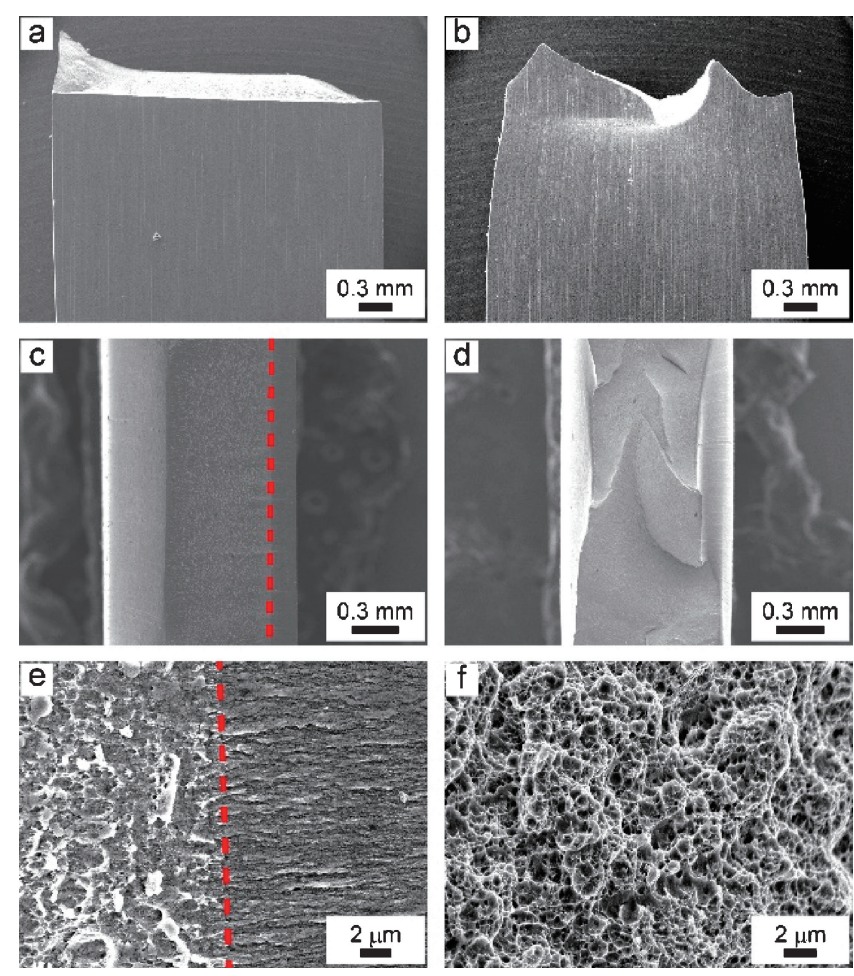

図15（a)，(b) 破断後の平行部拈よび(c)-(f) 破断面の SEM 像：(左側) 従来法, (右側) 断続添加法. (c), (e) 図中の赤色の破線は, $\mathrm{Ni}-\mathrm{B}$ 合金と純 $\mathrm{Ni}$ の境界を示している. 図中の破線右側が $\mathrm{Ni}-\mathrm{B}$ 合 金, 左側が純 $\mathrm{Ni}$ である ${ }^{(13)}$ （オンラインカラー)

が提案されるなど, 近年においても, ナノ結晶メタルの特性 発現メカニズムに関わる基礎的研究は盛んに行われている. これまでの報告では, 粒界安定性と機械的特性の関係は, 硬 さ測定を通して行われてきた。本稿に扔いては, 我々がこれ までに作製してきた高強度と高延性を示す電析バルクナノ結 晶 $\mathrm{Ni}$ 合金を用いることで, 粒界安定性と引張特性の関係に ついて言及を行った。粒界安定性と $0.2 \%$ 耐力との間には相 関が見られたが，引張伸びとの間には明確な関係は確認され なかった．実際に，引張伸びの大小に影響を及ぼしているの は熱処理の有無であった，この結果は, 電析ままの状態の電 析合金に扔いて特有の微細組織があり，これが伸びを支配し ている可能性を示しているのかもしれない, 他方, 電析プロ セスを用いたバルクナノ結晶 $\mathrm{Ni}$ 合金の作製においては，そ の作製プロセス固有の課題があり, 種々の溶質種による合金 化が困難であり, 比較試験の実施が難しい状況にある.この 状況を打開すべく, 分解性が高い試薬を溶質供給源に適用可 能とする断続添加法を紹介した. 本手法を用いることで, 従 来は作製が困難であったバルクナノ結晶 $\mathrm{Ni}$ 合金の作製が期 待される。

本研究の一部は, 公益財団法人永井科学技術財団の研究助 成によって実施されました。 また, TEM 観察は, 名古屋大 学微細構造解析プラットフォームの支援を受けて実施されま した. 


\section{文献}

(1) X. Li and K. Lu: Nat. Mater., 16(2017), 700.

(2) E. Ma and T. Zhu: Mater. Today, 20(2017), 323-331.

( 3 ) H. Gleiter: Prog. Mater Sci., 33 (1989), 223-315.

(4) C. Cheung, F. Djuanda, U. Erb and G. Palumbo: Nanostruct. Mater., 5(1995), 513-523.

( 5 ) R. Rofagha, U. Erb, D. Ostrander, G. Palumbo and K. T. Aust: Nanostruct. Mater., 2(1993), 1-10.

( 6 ) A. M. El-Sherik, U. Erb, G. Palumbo and K. T. Aust: Scr. Metall. Mater., 27 (1992), 1185-1188.

( 7 ) T. Yamasaki, P. Schlossmacher, K. Ehrlich and Y. Ogino: Nanostruct. Mater., 10(1998), 375-388.

( 8 ) J. Schioøtz and K. W. Jacobsen: Science, 301(2003), 13571359.

(9) L. Lu, L. B. Wang, B. Z. Ding and K. Lu: J. Mater. Res., 15 (2000), 270-273.

(10) A. A. Karimpoor, U. Erb, K. T. Aust and G. Palumbo: Scr. Mater., 49(2003), 651-656.

(11) K. M. Youssef, R. O. Scattergood, K. L. Murty, J. A. Horton and C. C. Koch: Appl. Phys. Lett., 87 (2005), 091904.

(12) K. Fujita, T. Suidu and T. Yamasaki: J. Japan Inst. Met., 75 (2011), 348-354.

(13) I. Matsui, N. Omura, T. Yamamoto and Y. Takigawa: Surf. Coat. Technol., 337 (2018), 411-417.

(14) I. Matsui, M. Kanetake, H. Hosokawa, N. Omura, Y. Takigawa and K. Higashi: Mater. Trans., 59(2018), 1354-1358.

(15) H. Mori, I. Matsui, Y. Takigawa, T. Uesugi and K. Higashi: Mater. Lett., 175(2016), 86-88.

(16) I. Matsui, T. Kawakatsu, Y. Takigawa, T. Uesugi and K. Higashi: Mater. Lett., 116 (2014), 71-74.

(17) I. Matsui, Y. Takigawa, T. Uesugi and K. Higashi: Mater. Sci. Eng. A, 578(2013), 318-322.

(18) I. Matsui: Materia Japan, 55(2016), 166-170.

(19) K. S. Kumar, S. Suresh, M. F. Chisholm, J. A. Horton and P. Wang: Acta Mater., 51 (2003), 387-405.

(20) J. Schiøtz, F. D. Di Tolla and K. W. Jacobsen: Nature, 391 (1998), 561-563.

(21) L. Wang, J. Teng, P. Liu, A. Hirata, E. Ma, Z. Zhang, M. Chen and X. Han: Nat. Commun., 5(2014), 4402.

(22) M. Legros, D. S. Gianola and K. J. Hemker: Acta Mater., 56 (2008), 3380-3393.

(23) I. A. Ovid'ko, R. Z. Valiev and Y. T. Zhu: Prog. Mater Sci., 94 (2018), 462-540.

(24) L. Wang, T. Xin, D. Kong, X. Shu, Y. Chen, H. Zhou, J. Teng, Z. Zhang, J. Zou and X. Han: Scr. Mater., 134(2017), 95-99.

(25) J. Weissmüller and J. Markmann: Adv. Eng. Mater., 7 (2005), 202-207.

(26) J. Hu, Y. N. Shi, X. Sauvage, G. Sha and K. Lu: Science, 355 (2017), 1292.

(27) D. Jang and M. Atzmon: J. Appl. Phys., 99(2006), 083504.

(28) S. Ranganathan, R. Divakar and V. S. Raghunathan: Scr. Mater., 44(2001), 1169-1174.

(29) X. L. Wu and Y. T. Zhu: Appl. Phys. Lett., 89(2006), 031922.

(30) A. Hasnaoui, H. Van Swygenhoven and P. M. Derlet: Acta Mater., 50(2002), 3927-3939.

(31) T. J. Rupert, J. R. Trelewicz and C. A. Schuh: J. Mater. Res., 27 (2012), 1285-1294.
(32) I. Matsui, H. Mori, T. Kawakatsu, Y. Takigawa, T. Uesugi and K. Higashi: Mater. Sci. Eng. A, 607 (2014), 505-510.

(33) O. Renk, A. Hohenwarter, K. Eder, K. S. Kormout, J. M. Cairney and R. Pippan: Scr. Mater., 95(2015), 27-30.

(34) I. Matsui, T. Yamamoto, N. Omura and Y. Takigawa: Mater. Sci. Eng. A, 709(2018), 241-246.

(35) Y. M. Wang, S. Cheng, Q. M. Wei, E. Ma, T. G. Nieh and A. Hamza: Scr. Mater., 51 (2004), 1023-1028.

(36) I. Brooks, G. Palumbo, G. D. Hibbard, Z. R. Wang and U. Erb: J. Mater. Sci., 46(2011), 7713-7724.

(37) I. Matsui and N. Omura: Mater. Trans., 59(2018), 123-128.

(38) F. Tang, D. S. Gianola, M. P. Moody, K. J. Hemker and J. M Cairney: Acta Mater., 60(2012), 1038-1047.

(39) A. Pineau, A. Amine Benzerga and T. Pardoen: Acta Mater. $107(2016), 508-544$

(40) M. Kanetake, Y. Takigawa, T. Uesugi and K. Higashi: Mater. Trans., 59(2018), 598-601.

(41) L. Qin, J. Lian and Q. Jiang: J. Alloys Compd., 504(2010), S439-S442.

（42）松井 功, 尾村直紀, 李 明軍, 村上雄一朗, 多田周二 : 表 面技術，67 (2016)，434-439.

(43) W. H. Safranek: The Properties of Electrodeposited Metals and Alloys, a Handbook, 2nd ed., AESF, Orlando, FL, (1986).

(44) I. Matsui, S. Ono, Y. Hanaoka, T. Uesugi, Y. Takigawa and K. Higashi: Philos. Mag. Lett., 94(2014), 63-71.

(45) I. Matsui, S. Ono, Y. Takigawa, T. Uesugi and K. Higashi Mater. Sci. Eng. A, 550(2012), 363-366.

(46) S. Higashino, M. Miyake, H. Fujii, A. Takahashi, R. Kasada and T. Hirato: Mater. Trans., 59(2018), 944-949.

(47) G. E. Ryschkewitsch: J. Am. Chem. Soc., 82(1960), 32903294.

(48) I. Matsui, M. Li and N. Omura: Mater. Trans., 58(2017), $1038-1041$

(49) Y. Takigawa, S. Wakayama, I. Matsui, T. Uesugi and K. Higashi: Mater. Trans., 52(2011), 37-40.

(50) I. Matsui, T. Uesugi, Y. Takigawa and K. Higashi: Acta Mater., 61 (2013), 3360-3369.

(51) W. M. Yin, S. H. Whang and R. A. Mirshams: Acta Mater., 53 (2005), 383-392.

52) W. M. Yin and S. H. Whang: Scr. Mater., 44(2001), 569-574.

\section{松井 功}

2011年-2014年 日本学術振興会特別研究員 (DC1)

2012年 4 月-8 月 トロント大学(留学)

2014年 3 月 大阪府立大学大学院工学研究科物質 ·化学系専攻博士後期課程 修了

2014年 4 月- 現職

専門分野 : ナノ結晶材料

○電析プロセスの開発を通して，バルクナノ結晶合金の作製やその機械的特 性の評価に取り組む。最近は，古典的な水溶液プロセスに加えて，非水溶 液溶媒を基礎とした新規な電析プロセスの開発にも着手している.

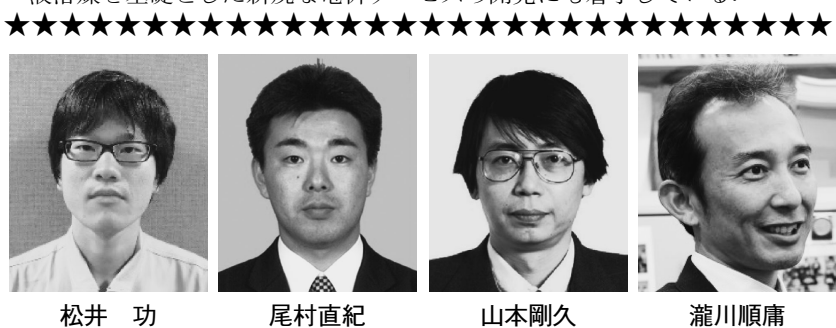

